\title{
Analisis Kekakuan dan Perilaku Portal Bidang Baja Hollow yang Diisi Mortar FAS 0,4 Dengan Variasi Ukuran Profil
}

\author{
Muhammad Rifqi ${ }^{1}$, Huzaim ${ }^{2}$, Rudiansyah Putra ${ }^{3}$ \\ ${ }^{1,2}$ Jurusan Teknik Sipil, Universitas Syiah Kuala, Bnda Aceh 23111, Indonesia \\ ${ }^{3}$ Mahasiswa Jurusan Teknik Sipil, Universitas Syiah Kuala, Banda Aceh 23111, Indonesia \\ Email:mr.rifqi19@gmail.com
}

\begin{abstract}
Hollow steel is a steel material that has a hollow in the middle, so it cannot withstand heavy loads. The addition of $0,4 \mathrm{w} / \mathrm{c}$ ratio of mortar into the hollow steel aims to cover the cavity. The value of stiffness in steel elements can be determined based on the sections and modulus elasticity. For composite elements the value of stiffness cannot be determined surely. This research was conducted to obtain the value of stiffness in the composite element. In this research used hollow steel material with variations of section 30/60 mm, 40/80 mm and 50/100 mm with $1 \mathrm{~mm}$ thickness grade of BJ 37 which is treated into a plane frame with height and width $800 \mathrm{~mm}$ from end to end. Material for making mortar is Portland cement type I, fine aggregate, water, and an additional material, namely viscocrete-10. After the research was finished, the capacity of plane frame was obtained for 30/60 section was 0,71 ton with displacement 23,45 mm, 40/80 section was 1,28 ton with displacement 40,41 mm and 50/10 section was 2,01 ton with displacement 37,64 mm. The value of plane frame stiffness at elasticity limit of 30/60 section was 77,778 kg/mm, 40/80 was 216,216 kg/mm and 50/100 was $448,529 \mathrm{~kg} / \mathrm{mm}$.
\end{abstract}

Keyword : hollow steel, plane frame, profile dimension, stiffness, composite

\begin{abstract}
Abstrak
Baja hollow adalah salah satu material baja yang memiliki rongga ditengahnya, sehingga tidak kuat menahan beban yang berat. Penambahan mortar FAS 0,4 pada rongga baja hollow bertujuan menutupi rongga tersebut. Pada elemen baja, nilai kekakuan dapat ditentukan berdasarkan dimensi dan modulus elastisitas. Untuk elemen komposit nilai kekakuannya belum dapat ditentukan secara pasti. Penelitian ini dilakukan untuk mendapatkan nilai kekakuan pada elemen komposit. Pada penelitian ini digunakan material baja hollow dengan variasi ukuran 30/60 mm, 40/80 mm dan 50/100 mm dengan ketebalan $1 \mathrm{~mm}$ mutu BJ 37 yang dirangkai menjadi portal bidang, dengan tinggi dan lebar $800 \mathrm{~mm}$ dari ujung ke ujung. Material penyusun mortar adalah semen Portland tipe I, agregat halus, air, dan bahan tambah viscocrete-10. Setelah penelitian dilaksanakan, diperoleh nilai kapasitas portal bidang pengujian profil 30/60 sebesar 0,71 ton dengan perpindahan 23,45 mm, profil 40/80 sebesar 1,28 ton dengan perpindahan 40,41 mm dan profil 50/100 sebesar 2,01 ton dengan perpindahan 37,64 mm. Nilai kekakuan portal bidang pada batas elasis profil 30/60 sebesar $77,778 \mathrm{~kg} / \mathrm{mm}$, profil 40/80 sebesar $216,216 \mathrm{~kg} / \mathrm{mm}$ dan profil $50 / 100$ sebesar $448,529 \mathrm{~kg} / \mathrm{mm}$.
\end{abstract}

Kata Kunci : baja hollow, portal bidang, ukuran profil, kekakuan, komposit

\section{Pendahuluan}

Baja hollow telah banyak digunakan pada pembuatan pagar, teralis, railing tangga, dan lain-lain. Dibandingkan dengan material kayu, baja hollow memiliki bobot yang lebih ringan, pemasangan yang lebih mudah, serta lebih ramah lingkungan. Namun untuk konstruksi struktural penggunaan baja hollow masih sangat kurang, dikarenakan memiliki lubang ditengahnya sehingga tidak kuat menahan beban yang berat. Penambahan mortar ke dalam baja hollow bertujuan menutupi kekosongan tersebut, sehingga bersifat lebih kaku dan mampu dalam menahan beban yang lebih berat.

Material yang digunakan pada penelitian ini adalah baja hollow dengan variasi ukuran 30/60 mm, 40/80 mm dan 50/100 mm dengan ketebalan $1 \mathrm{~mm}$ mutu BJ 37 yang diberi perlakuan menjadi portal bidang dengan tinggi dan lebar $800 \mathrm{~mm}$ dari ujung ke ujung. Mortar tersusun dari semen Portland tipe I, agregat halus, air, dan bahan tambah viscocrete 10 . Pembuatan benda uji dimulai dengan pemotongan baja hollow sesuai dengan tinggi dan ukuran yang direncanakan.
Tujuan dari penelitian ini adalah untuk mengetahui perilaku, kapasitas dan kekakuan portal bidang baja hollow yang telah diisi mortar. Manfaat dari penelitian ini adalah untuk memperoleh nilai kekakuan yang efektif pada elemen struktur yang bersifat komposit. Sehingga diharapkan portal bidang komposit ini dapat digunakan pada dunia konstruksi atau rumah sederhana, serta dapat menjadi solusi dalam membangun rumah hunian yang murah dan ramah lingkungan.

Setelah dilakukan pengujian pembebanan portal bidang, diperoleh kapasitas yang mampu dipikul oleh profil 30/60, 40/80, dan 50/100 secara berturut-turut yaitu sebesar 0,71 ton, 1,28 ton, dan 2,01 ton. Adapun nilai perpindahan yang terjadi secara berurutan sebesar 23,45 mm, 40,41 mm, dan 37,64 mm. Untuk nilai kekakuan pada daerah elastis yang diperoleh pada profil 30/60 sebesar $77,778 \mathrm{~kg} / \mathrm{mm}$, untuk profil 40/80 sebesar $216,216 \mathrm{~kg} / \mathrm{mm}$ dan profil $50 / 100$ nilai kekakuannya sebesar 448,529 kg/mm. Semakin besar ukuran profil yang digunakan, semakin besar juga nilai kekakuan dan kapasitas daya dukung struktur yang mampu dipikul portal bidang. 


\section{Tinajuan kepustakaan}

\subsection{Portal bidang}

Menurut Sitompul (2009) [1], portal (frame) adalah kerangka yang terdiri dari dua atau lebih bagian konstruksi yang di sambungkan guna mencapai stabilitas, umumnya dapat menahan gaya momen, gaya geser, dan gaya aksial. Kassimali (2010) [2] menyebutkan bahwa portal bidang (plane frame) dapat didefinisikan sebagai kumpulan elemen-elemen linear dua dimensi yang tergabung pada titik hubungannya secara kaku atau sembungan sendi, dan beban serta reaksi terjadi pada bidang struktur tersebut.

Untuk struktur komposit baja yang berisikan beton masih jarang ditemui. Struktur komposit disebut juga dengan batang tak homogen, dikarenakan stuktur tersebut terdiri dari gabungan 2 material, yaitu beton dan baja. Untuk memudahkan perhitungan pada penampang komposit digunakan angka ekivalensi (n), yang dihitung dengan persamaan berikut :

$n=\frac{E s}{E c}$..

$E_{s}=\frac{\sigma}{\varepsilon}$

$E_{c}=1,7 \times w^{2} \times \sqrt[3]{f^{\prime} c u}$

dimana $: n$ = Angka ekivalensi;

$E_{s} \quad=$ Modulus elastisitas baja (MPa);

$E_{c} \quad=$ Modulus elastisitas beton (MPa);

$\sigma \quad=$ Tegangan baja (MPa);

$\varepsilon \quad=$ Regangan baja;

$\mathrm{w} \quad=$ Berat mortar $\left(\mathrm{kg} / \mathrm{m}^{3}\right)$; dan

$f_{c u}^{\prime}=$ Kuat tekan beton kubus (MPa).

Wibowo (2011) [3] menyebutkan dengan bantuan angka ekivalensi maka penampang komposit tersebut akan diekivalensi menjadi penampang yang homogen, sehingga perhitungan menjadi sederhana seperti penampang homogeny.

\subsection{Baja hollow}

Menurut Sardika (2014) [4], baja hollow merupakan bagian dari profil baja yang memiliki penampang berbentuk lingkaran, bujur sangkar (square hollow section), atau persegi panjang (rectangular hollow section). Dalam SNI 03-1729-2002 [7] telah dijelaskan secara keseluruhan karakteristik dan sifat-sifat mekanis profil baja hollow sama dengan profil baja struktural.

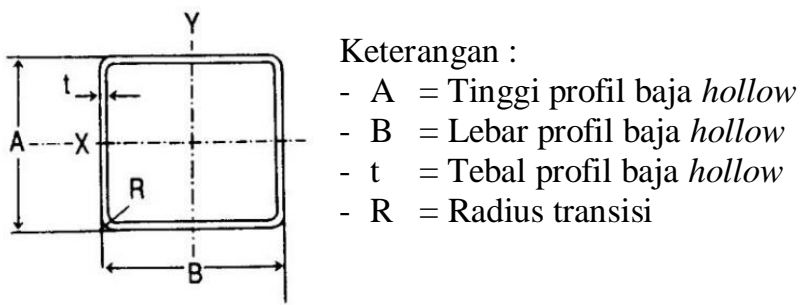

\section{Gambar 1 Profil Baja Hollow}

Pada profil baja hollow, tegangan leleh, tegangan tarik dan modulus elastisitas dapat diperoleh dengan pengujian kuat tarik. Standar acuan yang digunakan pada SNI 8389-2017 Cara Uji Tarik Logam [9]. Pengujian dilakukan menggunakan mesin uji tarik (Universal Strength Tester) Mohr and Federhaff AG No. UPD. 107385/1970 produksi Mannheim Germany dengan kapasitas maksimum pembebanan 10 ton.

\subsection{Sambungan las}

Menurut Setiawan (2013) [5], pengelasan adalah suatu proses penyambungan bahan logam yang menghasilkan peleburan bahan dengan memanasinya hingga suhu yang tepat dengan atau tanpa pemberian tekanan dan dengan atau tanpa pemakaian bahan pengisi. Las sudut (fillet welds) yaitu tipe las yang paling banyak dijumpai dibandingkan tipe las yang lain, 80\% sambungan las menggunakan tipe las sudut. Tidak memerlukan presisi tinggi dalam pengerjaannya.. Sambungan las memiliki banyak keuntungan, dari segi ekonomi harga konstruksi dengan menggunakan las lebih murah dibandingkan dengan pemakaian baut atau keling. Pada konstruksi rangka jembatan bahkan dapat mengurangi berat baja hingga $15 \%$ jika dipakai sambungan las

\subsection{Pelat buhul}

Pelat buhul (Gusset plate) adalah sistem sambungan memakai pelat baja, bisa tunggal atau berpasangan. Fungsinya adalah untuk menyatukan elemen-elemen dari struktur rangka batang (truss). Pelat buhul mimiliki peran yang sangat penting didalam struktur rangka baja. Pelat buhul ditambahkan pada kedua sisi joint yang kemudian disambung mengunakan las.

\subsection{Mortar}

Standar Nasional Indonesia (SNI) 15-2049-2004 [7], menjelaskan bahwa mortar adalah suatu campuran yang terdiri dari semen, agregat halus, dan air baik dalam keadaan dikeraskan ataupun tidak dikeraskan. Agregat halus merupakan pasir yang lolos saringan $4,76 \mathrm{~mm}$. Kekuatan mortar dipengaruhi oleh rasio air semen, sehingga untuk meningkatkan mutu mortar bisa didapatkan dengan cara mengurangi rasio air.

\subsection{Bahan tambah (admixture)}

Secara umum bahan tambah dalam beton dapat dibedakan menjadi dua, yaitu bahan tambah yang bersifat kimiawi dan bahan tambah yang bersifat mineral. Bahan tambah digunakan untuk memodifikasi sifat dan karakteristik dari beton, untuk meningkatkan kinerja beton sesuai dengan kondisi yang dibutuhkan pada situasi-situasi tertentu. Bahan tambah yang digunakan yaitu viscocrete-10 sebanyak $1 \%$ dari kadar semen.

\subsection{Metode analisis portal bidang}

Analisis struktural, yang merupakan bagian integral dari setiap proyek rekayasa struktural, adalah proses memprediksi kinerja struktur tertentu dalam kondisi pemberian beban. Wahyuni (2011) [6] menyebutkan analisa struktur metode matriks adalah suatu metode untuk menganalisa struktur dengan menggunakan bantuan matriks yang terdiri dari matriks kekakuan, matriks perpindahan, dan matriks gaya. Dengan menggunakan hubungan :

$$
\begin{aligned}
\{\mathrm{P}\}=[\mathrm{K}]\{\mathrm{U}\} & \\
\text { dimana: } \quad\{\mathrm{P}\} & =\text { Matriks gaya; } \\
{[\mathrm{K}] } & =\text { Matriks kekakuan; dan } \\
\{\mathrm{U}\} & =\text { Matriks perpindahan. }
\end{aligned}
$$


Perhitungan analisis matriks portal bidang (plane frame) berdasarkan Matrix Analysis of Structures, Second Edition (Kassimali, 2010) [2] adalah sebagai berikut :
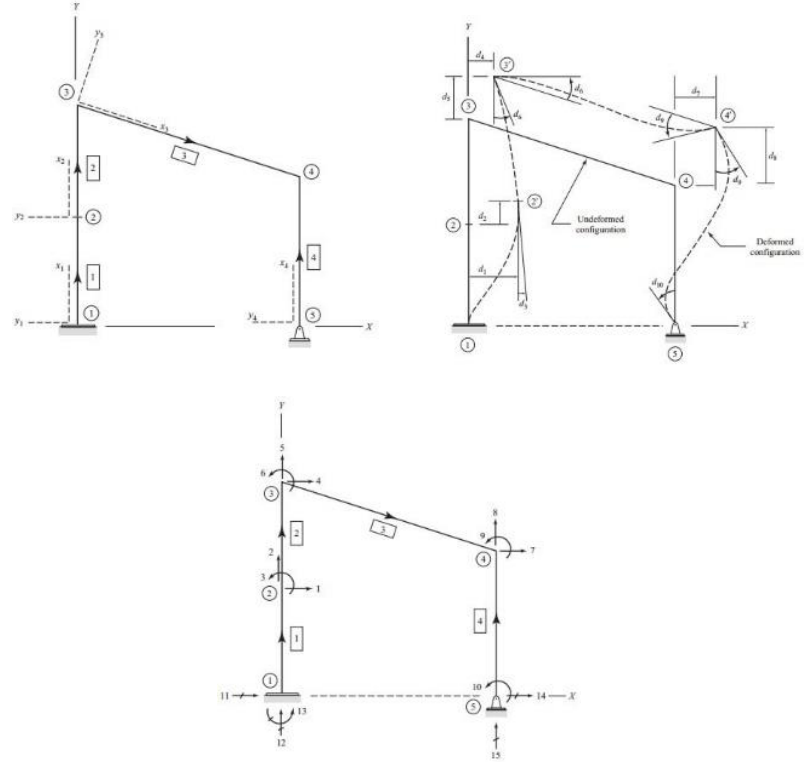

Gambar 2 Model analisis sistem koordinat global dan sistem koordinat local metode matriks

$L=\sqrt{\left(x_{j}-x_{i}\right)^{2}+\left(y_{j}-y_{i}\right)^{2}}$.

$C=\cos \theta=\frac{x_{j}-x_{i}}{L}$

$S=\sin \theta=\frac{y_{j}-y_{i}}{L}$.

Matriks tranformasi :

$\left.[T]=\left[\begin{array}{cccccc}\cos \theta & \sin \theta & 0 & 0 & 0 & 0 \\ -\sin \theta & \cos \theta & 0 & 0 & 0 & 0 \\ 0 & 0 & 1 & 0 & 0 & 0 \\ 0 & 0 & 0 & \cos \theta & \sin \theta & 0 \\ 0 & 0 & 0 & -\sin \theta & \cos \theta & 0 \\ 0 & 0 & 0 & 0 & 0 & 1\end{array}\right] \ldots \ldots \ldots \ldots \ldots . . . \ldots\right)$

Matriks transpose dari matriks transformasi

$\left.\left[T^{T}\right]=\left[\begin{array}{cccccc}\cos \theta & -\sin \theta & 0 & 0 & 0 & 0 \\ \sin \theta & \cos \theta & 0 & 0 & 0 & 0 \\ 0 & 0 & 1 & 0 & 0 & 0 \\ 0 & 0 & 0 & \cos \theta & -\sin \theta & 0 \\ 0 & 0 & 0 & \sin \theta & \cos \theta & 0 \\ 0 & 0 & 0 & 0 & 0 & 1\end{array}\right] \ldots \ldots \ldots \ldots \ldots \ldots\right)$

Matriks kekakuan elemen koordinat lokal :

$[k]=\frac{E I}{L^{3}}\left[\begin{array}{cccccc}\frac{A L^{2}}{I} & 0 & 0 & -\frac{A L^{2}}{I} & 0 & 0 \\ 0 & 12 & 6 L & 0 & -12 & 6 L \\ 0 & 6 L & 4 L^{2} & 0 & -6 L & 2 L^{2} \\ -\frac{A L^{2}}{I} & 0 & 0 & \frac{A L^{2}}{I} & 0 & 0 \\ 0 & -12 & -6 L & 0 & 12 & -6 L \\ 0 & 6 L & 2 L^{2} & 0 & -6 L & 4 L^{2}\end{array}\right] \ldots$

Matriks kekakuan elemen koordinat global :

$[K]=\left[T^{T}\right][k][T]$.

Kemudian dicari matriks kekakuan struktur

koordinat lokal, matriks kekakuan struktur secara keseluruhan [S], invers matriks kekakuan struktur secara keseluruhan $\left[S^{-1}\right]$, dan masukkan gaya yang bekerja terhadap konstruksi. Perpindahan struktur yang timbul :

$[d]=\left[S^{-1}\right][P]$.

Perpindahan akhir elemen sistem koordinat lokal :

$[u]=[T][v]$

Gaya akhir elemen pada sistem koordinat lokal :

$[Q]=[k][u]$.

Gaya akhir elemen pada sistem koordinat global :

$[F]=\left[T^{T}\right][Q]$.
Dimana :

$[\mathrm{K}]=$ Matriks kekakuan elemen koordinat global;

[T] = Matriks transformasi;

[k] = Matriks kekakuan elemen koordinat lokal;

[d] = Perpindahan struktur;

[S] = Matriks kekakuan struktur secara keseluruhan;

[P] = Beban yang diberikan;

[u $]=$ Perpindahan akhir elemen koordinat lokal;

[v] = Perpindahan akhir elemen koordinat global;

[Q] = Gaya akhir elemen koordinat lokal; dan

[F] = Gaya akhir elemen koordinat global.

\section{Kekakuan Struktur}

Kassimali (2010) [2] menyebutkan bahwa metode kekakuan juga disebut metode perpindahan atau kesetimbangan. Besaran kekakuan suatu bahan adalah nilai modulus elastisitasnya, yang didapat dengan membagi tegangan satuan yang diterima bahan dengan perubahan satuan bentuk bahan tersebut. Kekakuan merupakan sifat yang mampu meregang pada tegangan tinggi tanpa diikuti regangan yang besar. Untuk mencari nilai kekakuan struktur portal bidang dapat digunakan persamaan berikut : $\mathrm{k}=\frac{P}{d}$

dimana : $\mathrm{k}=$ Kekakuan $(\mathrm{kg} / \mathrm{mm})$;

$\mathrm{P}=$ Beban $(\mathrm{kg})$; dan

$\mathrm{d}=$ Perpindahan $(\mathrm{mm})$;

\section{Metodologi penelitian}

\subsection{Perencanaan struktur portal bidang}

Ada 3 tipe struktur portal bidang yang dianalisis pada penelitian ini. Tipe-tipe tersebut memiliki ukuran profil $30 / 60 \mathrm{~mm}, 40 / 80 \mathrm{~mm}$, dan $50 / 100 \mathrm{~mm}$ dengan ketebalan $1 \mathrm{~mm}$ mutu BJ37 dengan tinggi dan lebar portal bidang $800 \mathrm{~mm}$ dari ujung ke ujung.

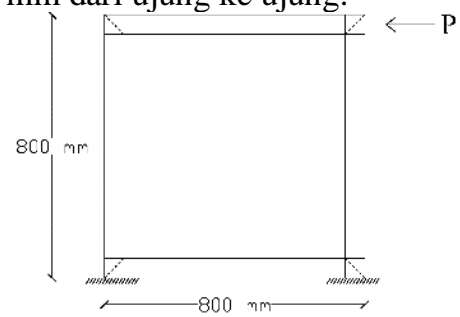

Gambar 3 Desain benda uji portal bidang

Tabel 1 Tipe benda uji portal bidang

\begin{tabular}{cc} 
Portal Bidang & Ukuran Profil Baja Hollow $(\mathrm{mm})$ \\
\hline PBK-A & $30 \times 60$ \\
\hline PBK-B & $40 \times 80$ \\
\hline PBK-C & $50 \times 100$
\end{tabular}

\subsection{Pemotongan baja hollow}

Tahap awal dari pembuatan benda uji portal bidang dimulai dengan pemotongan profil baja hollow menggunakan gerinda. Profil baja hollow yang dipotong berukuran 30/60 mm, 40/80 mm, dan 50/100 mm dengan tebal $1 \mathrm{~mm}$ untuk perakitan total 3 benda uji portal bidang dengan tinggi dan lebar portal $800 \mathrm{~mm}$. Untuk satu benda uji portal bidang dibutuhkan 4 batang baja hollow dengan panjang $800 \mathrm{~mm}$. 


\subsection{Pengecoran dan pengisian mortar}

Pengecoran mortar diawali dengan memasukkan material pasir, semen, air, dan viscocrete-10 ke dalam concrete mixer. Biarkan concrete mixer berputar sampai material tersebut tercampur secara merata. Selanjutnya mortar diisi ke dalam lubang baja hollow secara manual hingga mortar memenuhi lubang baja hollow. Salah satu ujung baja hollow ditutup agar mortar tidak keluar dari lubang sampai mengeras.

\subsection{Perawatan benda uji}

Perawatan benda uji portal bidang dilakukan dengan cara dicat dan metode water curing. Benda uji portal bidang ditutup dengan goni yang selanjutnya disiram dengan air secara rutin selama 21 hari. Perawatan ini dilakukan di Laboratorium Konstruksi dan Bahan Bangunan Fakultas Teknik Universitas Syiah Kuala.

\subsection{Perangkaian portal bidang baja hollow}

Setelah mortar mengeras dan dilakukan perawatan selama 21 hari, pada setiap ujung batang baja hollow dipotong dengan sudut kemiringan $45^{\circ}$, kemudian antara satu batang dengan batang lainnya dilas sesuai dengan perencanaan sehingga membentuk benda uji portal bidang. Pada setiap joint ditambahkan pelat buhul pada kedua sisi, dengan tujuan untuk menghindari kegagalan joint dan untuk menambah kekuatan pada sambungan.

\subsection{Pengujian pembebanan portal bidang}

Pengujian pembebanan portal bidang dilakukan diatas load frame dengan cara diberikan beban terpusat arah horizontal menggunakan load cell 50 ton. Pengujian dilakukan setelah benda uji portal bidang berumur 28 hari. Pada saat pengujian pembebanan portal bidang digunakan LVTD sebanyak 4 buah untuk pembacaan perpindahan (displacement). Pembacaan dengan alat LVDT tercatat pada data logger. Set-up LVDT pada portal bidang ditunjukan pada Gambar 3.5.

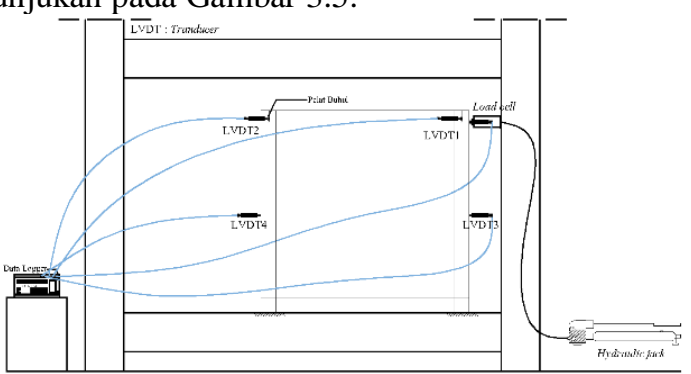

Gambar 4 Set-up benda uji portal bidang

\subsection{Analisis Data}

\subsubsection{Analisis kapasitas portal bidang}

Tinjauan dari kapasitas berupa beban dan perpindahan dari benda uji portal bidang, yaitu dengan menggunakan grafik hubungan beban-perpindahan. Kapasitas struktur dapat dilihat dari besarnya beban maksimum yang mampu dipikul oleh struktur portal bidang.

\subsubsection{Analisis kekakuan portal bidang}

Kekakuan pada struktural dapat diperoleh dari hasil pengujian pembebanan, berupa grafik hubungan beban dan perpindahan. Kekakuan diperoleh dari rasio perbandingan antara beban yang diterima portal bidang dengan perpindahan yang terjadi ketika portal bidang diberikan beban.

\section{Hasil dan pembahasan}

\subsection{Hasil pengujian kuat tarik baja hollow}

Dari data hasil pengujian kuat tarik baja hollow digunakan persamaan untuk memperoleh nilai tegangan leleh $\left(\sigma_{y}\right)$, regangan leleh $\left(\varepsilon_{y}\right)$ dan modulus elastisitas $(\mathrm{E})$ baja hollow yang digunakan pada penelitian ini. Benda uji dibuat sesuai standar SNI 8389-2017 "Cara Uji Tarik Logam" [9] di Laboratorium Konstruksi dan Bahan Bangunan (LKBB) Fakultas Teknik Universitas Syiah Kuala. Data hasil pengujian diperlihatkan pada tabel berikut.

Tabel 2 Hasil Perhitungan Uji Tarik Baja Hollow

\begin{tabular}{cccc}
\hline $\begin{array}{c}\text { Benda } \\
\text { Uji }\end{array}$ & $\begin{array}{c}\text { Tegangan } \\
\text { Leleh } \\
(\mathrm{MPa})\end{array}$ & $\begin{array}{c}\text { Regangan } \\
\text { Leleh }\end{array}$ & $\begin{array}{c}\text { Modulus } \\
\text { Elastisitas (MPa) }\end{array}$ \\
\hline (a) & $(\mathrm{b})$ & $(\mathrm{c})$ & $(\mathrm{d})=(\mathrm{b}) /(\mathrm{c})$ \\
\hline Hollow & 240 & 0,0012 & 200.000 \\
\hline
\end{tabular}

\subsection{Hasil pengujian kuat tekan kubus mortar}

Pada setiap benda uji portal bidang dilakukan pengujian kuat tekan kubus sebanyak 3 buah, dengan jumlah 9 kubus untuk 3 benda uji portal bidang. Pengujian kuat tekan ini dilakukan sebagai kontrol terhadap mutu mortar yang digunakan sebagai bahan pengisi pada baja hollow portal bidang. Pengujian ini dilakukan ketika benda uji berumur 7, 14 dan 28 hari. Hasil data pengujian kuat tekan kubus mortar dapat tabel berikut.

Tabel 3 Hasil Pengujian Kuat Tekan Benda Uji Kubus Mortar

\begin{tabular}{|c|c|c|c|c|c|}
\hline No. & $\begin{array}{c}\text { Berat } \\
(\mathrm{W})\end{array}$ & $\begin{array}{c}\text { Beban } \\
\text { (P) }\end{array}$ & $\begin{array}{l}\text { Kuat } \\
\text { Tekan } \\
(\mathrm{f} \mathrm{cu})\end{array}$ & $\begin{array}{l}\text { Kuat } \\
\text { Tekan } \\
\text { (f'cu) }\end{array}$ & $\begin{array}{l}\text { Umur } \\
\text { Kubus }\end{array}$ \\
\hline & $(\mathrm{kg})$ & $(\mathrm{kg})$ & (MPa) & (MPa) & hari \\
\hline A & 0,136 & 11000 & 35,888 & \multirow{3}{*}{33,551} & \multirow{3}{*}{7} \\
\hline B & 0,122 & 10000 & 33,213 & & \\
\hline $\mathrm{C}$ & 0,122 & 9500 & 31,553 & & \\
\hline A & 0,312 & 12000 & 38,308 & \multirow{3}{*}{38,408} & \multirow{3}{*}{14} \\
\hline B & 0,326 & 13500 & 42,283 & & \\
\hline $\mathrm{C}$ & 0,314 & 11500 & 34,634 & & \\
\hline A & 0,318 & 11000 & 33,815 & \multirow{3}{*}{40,020} & \multirow{3}{*}{28} \\
\hline B & 0,28 & 14300 & 48,484 & & \\
\hline $\mathrm{C}$ & 0,284 & 10700 & 37,759 & & \\
\hline
\end{tabular}

\subsection{Hasil pengujian portal bidang}

Pada pengujian laboratorium ini terdiri dari tiga benda uji portal bidang, yaitu benda uji PBK-A (30/60), PBK-B (40/80) dan PBK-C (50/100). Menurut pengamatan hasil pengujian, setiap variasi ukuran profil portal bidang komposit mengalami kehancuran pada elemen kolom. Dikarenakan beban yang bekerja beban terpusat pada arah horizontal, sehingga elemen kolom menghasilkan momen yang lebih besar. 
4.3.1 Benda uji PBK-A (30/60)

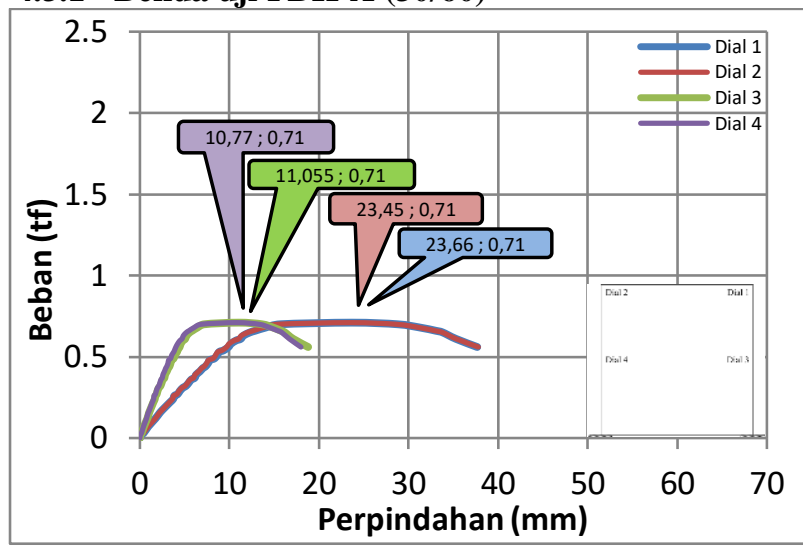

Gambar 5 Grafik beban-perpindahan struktur PBK-A

Pembacaan data beban-perpindahan menggunakan DIAL 2. Beban maksimum yang terjadi pada PBK-A yaitu sebesar 0,71 ton. Perpindahan yang terjadi ketika beban maksimum tercapai sebesar 23,45 mm.

\subsubsection{Benda uji PBK-B (40/80)}

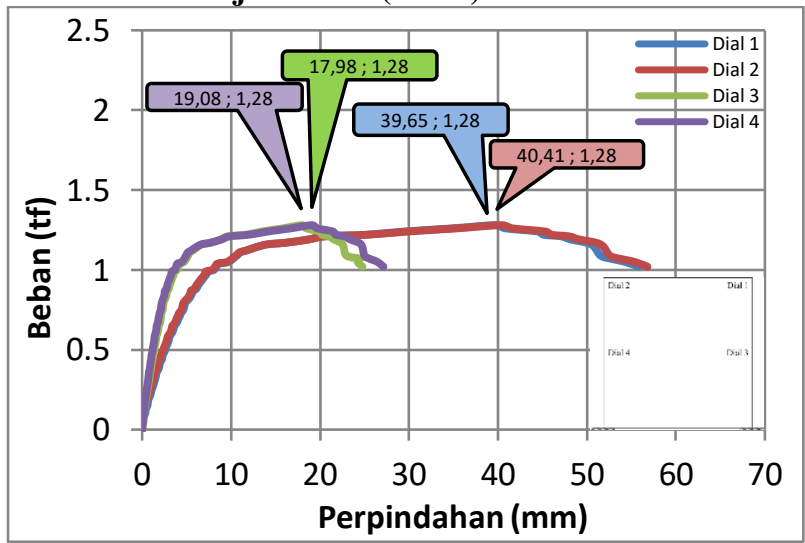

Gambar 6 Grafik beban-perpindahan struktur PBK-B

Pembacaan data beban-perpindahan menggunakan DIAL 2. Beban maksimum yang terjadi pada PBK-A yaitu sebesar 1,28 ton. Perpindahan yang terjadi ketika beban maksimum tercapai sebesar 40,41 $\mathrm{mm}$.

\subsubsection{Benda uji PBK-C (50/100)}

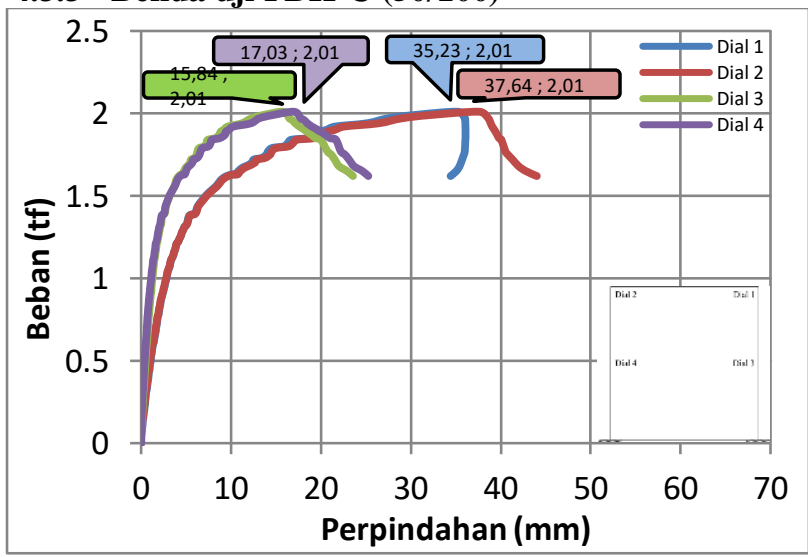

Gambar 7 Grafik beban-perpindahan struktur PBK-C

Pembacaan data beban-perpindahan menggunakan DIAL 2. Beban maksimum yang terjadi pada PBK-A yaitu sebesar 2,01 ton. Perpindahan yang terjadi ketika beban maksimum tercapai sebesar 37,64 mm.

\subsubsection{Hasil perhitungan teoritis portal bidang}

Beban maksimum yang diperoleh PBK-A (30/60) sebesar $651,588 \mathrm{~kg}$ dengan perpindahan struktur sebesar 7,675 mm. Pada PBK-B (40/80) diperoleh beban maksimum sebesar $1205,307 \mathrm{~kg}$ dengan perpindahan struktur sebesar $5,521 \mathrm{~cm}$. Sedangkan nilai beban maksimum PBK-C (50/100) adalah 1967,552 kg dengan perpindahan struktur sebesar 4,358 $\mathrm{mm}$. Dari hasil perhitungan teoritis yang telah dijabarkan, dapat diambil hipotesa awal bahwa semakin besar ukuran profil benda uji portal bidang yang digunakan, nilai kapasitas daya dukung yang mampu diterima juga semakin meningkat.

\subsection{Analisis kapasitas portal bidang hasil} pengujian

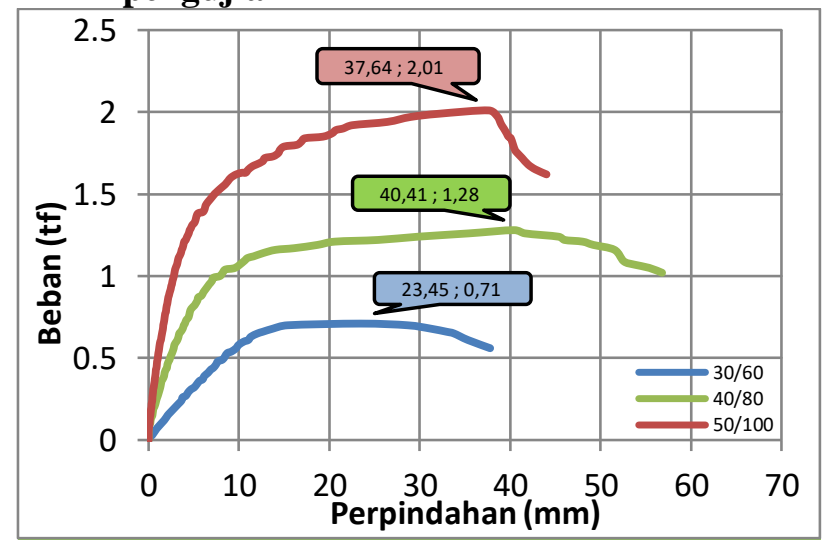

Gambar 8 Perbandingan Beban-Perpindahan Struktur Maksimum Profil 30/60, 40/80 dan 50/100 pada LVDT 2

Tabel 4 Rasio Nilai Kapasitas Portal Bidang Komposit

\begin{tabular}{cccc}
\hline $\begin{array}{c}\text { Profil } \\
\text { Benda } \\
\text { Uji }\end{array}$ & $\begin{array}{c}\text { Beban } \\
\text { Maksimum } \\
\text { (ton) }\end{array}$ & $\begin{array}{c}\text { Perpindahan } \\
(\mathbf{m m})\end{array}$ & $\begin{array}{c}\text { Rasio Nilai } \\
\text { Kapasitas } \\
\text { Terhadap } \\
\text { Profil 30/60 }\end{array}$ \\
\hline $30 / 60$ & 0,71 & 23,45 & 1 \\
\hline $40 / 80$ & 1,28 & 40,41 & 1,803 \\
\hline $50 / 100$ & 2,01 & 37,64 & 2,831 \\
\hline
\end{tabular}

Benda uji portal bidang profil $40 / 80$ mengalami kenaikan nilai beban dengan rasio sebesar 1,803 terhadap benda uji portal bidang profil 30/60. Untuk portal bidang profil 50/100 juga mengalami kenaikan nilai beban dengan rasio sebesar 1,57 terhadap benda uji portal bidang profil 40/80 dan 2,831 terhadap benda uji portal bidang profil 30/60. Dengan data yang diperoleh dapat diambil kesimpulan bahwa semakin besar ukuran profil benda uji, maka semakin besar nilai kapasitas struktur yang mampu dipikul oleh benda uji.

\subsection{Perbandingan kapasitas hasil perhitungan teoritis dengan hasil pengujian laboratorium}

Setelah diperoleh hasil perhitungan secara teoritis dan hasil pengujian laboratorium seperti yang telah dijabarkan pada hasil, nilai kapasitas keduanya akan direkap untuk memperoleh data perbandingan. Perbandingan hasil perhitungan secara teoritis dan hasil pengujian laboratorium untuk benda uji portal bidang profil 30/60, 40/80 dan 50/100 ditampilkan pada gambar berikut. 


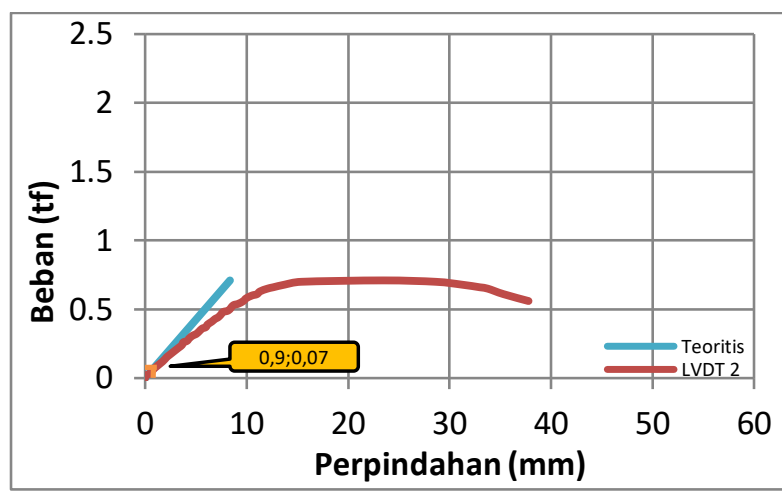

Gambar 9 Grafik Perbandingan Hasil Perhitungan Teoritis dan Hasil Pengujian Laboratorium PBK-A

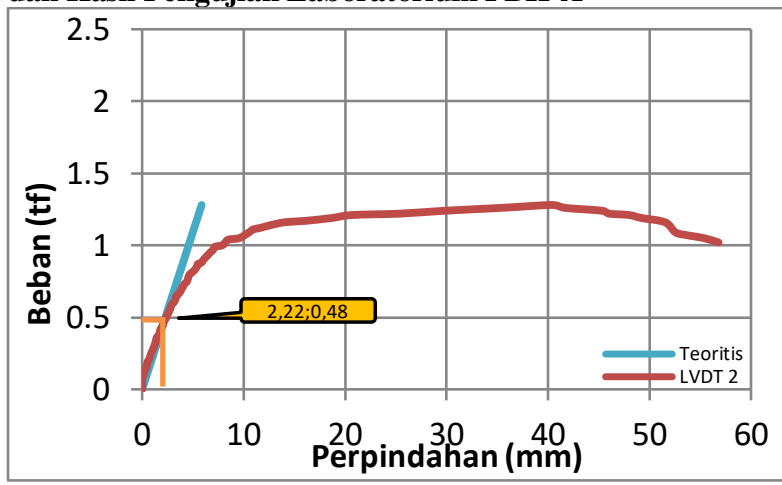

Gambar 10 Grafik Perbandingan Hasil Perhitungan Teoritis dan Hasil Pengujian Laboratorium PBK-B

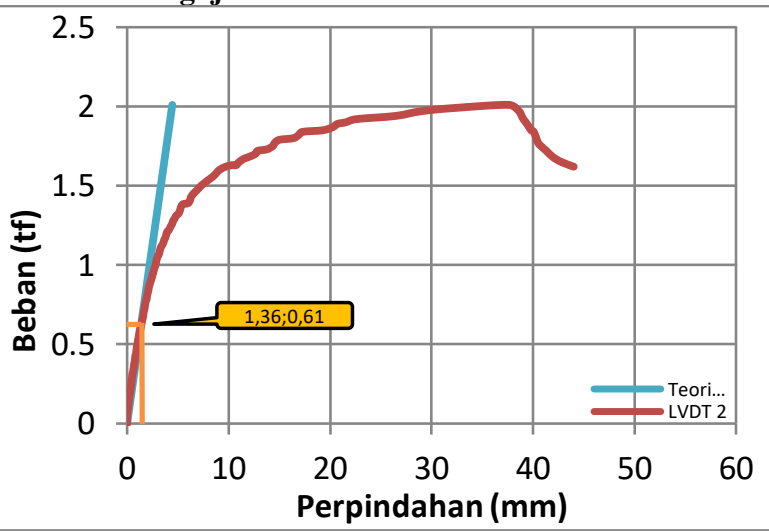

Gambar 11 Grafik Perbandingan Hasil Perhitungan Teoritis dan Hasil Pengujian Laboratorium PBK-C

Perhitungan kapasitas secara teoritis dianggap elastis sempurna, sehingga nilai kapasitas terus meningkat secara linier. Sedangkan untuk hasil pengujian laboratorium tidak elastis sempurna. Untuk hasil pengujian pada tahap awal pembebanan portal melewati batas elastis, kemudian memasuki daerah plastis sampai keadaan beban maksimum hingga mengalami kegagalan struktur.

Nilai kapasitas pada hasil pengujian pada saat batas elastis berada pada garis yang sama dengan perhitungan teoritis sampai pada beban tertentu. Hal tersebut terjadi ketika hasil pengujian portal bidang masih pada daerah elastis, nilai kapasitas keduanya meningkat secara linier Secara berturut-turut profil 30/60, 40/80 dan 50/100 mengalami beban-perpindahan yang sama antara perhitungan teoritis dengan pengujian laboratorium pada beban $70 \mathrm{~kg}, 480 \mathrm{~kg}$ dan $610 \mathrm{~kg}$ dengan perpindahan sebesar $0,9 \mathrm{~mm}, 2,22 \mathrm{~mm}$. dan $1,36 \mathrm{~mm}$.

\subsection{Analisis kekakuan struktur portal bidang teoritis dan hasil pengujian}

Nilai kekakuan struktur portal bidang dianalisis pada batas elastis dan beban maksimum. Pada perhitungan teoritis perhitungan benda uji dianggap elastis sempurna, sehingga nilai kekakuan pada batas elastis dan beban maksimum nilainya mendekati atau sama. Sedangkan untuk hasil pengujian dianalisis pada keduanya. Karena pada hasil pengujian portal bidang tidak pada keadaan elastis sempurna.

Tabel 5 Rasio Nilai Kekakuan Portal Bidang Pada Batas Elastis

\begin{tabular}{cccc}
\hline $\begin{array}{c}\text { Profil } \\
\text { Benda } \\
\text { Uji }\end{array}$ & $\begin{array}{c}\text { Kekakuan } \\
\text { Perhitungan } \\
\text { Teoritis } \\
(\mathrm{kg} / \mathrm{mm})\end{array}$ & $\begin{array}{c}\text { Kekakuan } \\
\text { Hasil } \\
\text { Pengujian } \\
(\mathrm{kg} / \mathrm{mm})\end{array}$ & $\begin{array}{c}\text { Rasio Nilai } \\
\text { Kekakuan } \\
\text { Terhadap } \\
\text { Teoritis }\end{array}$ \\
\hline $30 / 60$ & 84,897 & 77,778 & 0,916 \\
\hline $40 / 80$ & 218,313 & 216,216 & 0,99 \\
\hline $50 / 100$ & 451,48 & 448,559 & 0,993 \\
\hline
\end{tabular}

Tabel 6 Rasio Nilai Kekakuan Portal Bidang Pada Beban Maksimum

\begin{tabular}{cccc}
\hline $\begin{array}{c}\text { Profil } \\
\text { Benda } \\
\text { Uji }\end{array}$ & $\begin{array}{c}\text { Kekakuan } \\
\text { Perhitungan } \\
\text { Teoritis } \\
(\mathrm{kg} / \mathrm{mm})\end{array}$ & $\begin{array}{c}\text { Kekakuan } \\
\text { Hasil } \\
\text { Pengujian } \\
(\mathrm{kg} / \mathrm{mm})\end{array}$ & $\begin{array}{c}\text { Rasio Nilai } \\
\text { Kekakuan } \\
\text { Terhadap } \\
\text { Teoritis }\end{array}$ \\
\hline $30 / 60$ & 84,897 & 30,277 & 0,357 \\
\hline $40 / 80$ & 218,313 & 31,675 & 0,145 \\
\hline $50 / 100$ & 451,48 & 53,401 & 0,003 \\
\hline
\end{tabular}

Berdasarkan pada tabel rasio nilai kekakuan portal bidang hasil pengujian terhadap perhitungan teoritis pada batas elastis. Pada portal bidang profil $30 / 60$ memiliki rasio nilai kekakuan sebesar 0,916 , untuk portal bidang profil 40/80 memiliki rasio nilai kekakuan sebesar 0,99 dan untuk portal bidang profil 50/100 memiliki rasio nilai kekakuan sebesar 0,993. Dengan data yang diperoleh dapat diambil kesimpulan bahwa, untuk nilai kekakuan pada batas elastis, memiliki nilai rasio kecocokan yang tinggi. Hal ini menunjukkan bahwa perhitungan pada batas elastis mengalami kesesuaian.

Dapat dilihat pada tabel rasio nilai kekakuan portal bidang hasil pengujian terhadap perhitungan teoritis pada beban maksimum. Pada portal bidang profil 30/60 memiliki rasio nilai kekakuan sebesar 0,357 , untuk portal bidang profil 40/80 memiliki rasio nilai kekakuan sebesar 0,145 dan untuk portal bidang profil 50/100 memiliki rasio nilai kekakuan sebesar 0,003 . Berdasarkan rasio nilai kekakuan yang telah dijabarkan, dapat diambil kesimpulan bahwa hanya sebagian kecil yang mengalami kecocokan. Hal itu dikarenakan ketika dilapangan struktur bekerja tidak selalu pada keadaan elastis sempurna.

\section{Kesimpulan}

Kesimpulan dari hasil pengujian portal bidang baja hollow yang diisi mortar FAS 0,4 dengan variasi ukuran profil adalah sebagai berikut:

1. Perbandingan nilai kapasitas portal bidang memiliki nilai yang sama sampai pada satu titik. Untuk profil 30/60 memiliki nilai yang sama 
sampai pada beban $70 \mathrm{~kg}$ dengan perpindahan $0,9 \mathrm{~mm}$. Untuk profil 40/80 keduanya memiliki nilai yang sama sampai pada beban $480 \mathrm{~kg}$ dengan perpindahan 2,22 $\mathrm{mm}$. Sedangkan untuk profil 50/100 keduanya memiliki nilai yang sama sampai pada beban $610 \mathrm{~kg}$ dengan perpindahan $1,36 \mathrm{~mm}$.

2. Beban maksimum untuk portal bidang 30/60 sebesar 0,71 ton dengan perpindahan $23,45 \mathrm{~mm}$. Untuk portal bidang 40/80 sebesar 1,28 ton dengan perpindahan $40,41 \mathrm{~mm}$. Sedangkan untuk portal bidang 50/100 sebesar 2,01 ton dengan perpindahan $37,64 \mathrm{~mm}$. Rasio peningkatan nilai kapasitas profil 40/80 terhadap profil $30 / 60$ sebesar 1,803 , untuk profil $50 / 100$ terhadap profil 30/60 sebesar 2,831.

3. Rasio nilai kekakuan portal bidang hasil pengujian terhadap perhitungan pada batas elastis secara berturut-turut pada profil 30/60, 40/80 dan 50/100 sebesar 0,916, 0,99 dan 0,993. Sedangkan untuk rasio nilai kekakuan portal bidang hasil pengujian terhadap perhitungan pada beban maksimum secara berturut-turut pada profil 30/60, 40/80 dan 50/100 sebesar $0,357,0,145$ dan 0,003 . Nilai kekakuan pada batas elastis memiliki kecocokan yang sangat tinggi, sedangkan pada beban maksimum memiliki kecocokan yang sangat rendah.

4. Kehancuran benda uji balok 30/60 mm, 40/80 $\mathrm{mm}$, dan 50/100 mm pada keadaan yang sama, yaitu pada kolom portal bidang.

\section{Daftar pustaka}

[1] Sitompul, E., 2009, Analisa Struktur Pada Plane Frame dengan Menggunakan Metode Cross dan Finite Element Method, Tugas Akhir, Universitas Sumatera Utara, Medan.

[2] Kassimali, A., 2010, Matrix Analysis of Structures Second Edition, Cengage Learning, Stamford-USA.

[3] Wibowo, B., 2011, Mekanika Rekayasa 2, Bahan Ajar, Institut Teknologi Sepuluh November, Surabaya.

[4] Sardika, L., 2014, Kekuatan Portal Bidang (Plane Frame) Satu Pias Profil Baja Hollow Berdinding Beton Ringan Busa Dibebani Beban Horizontal Dengan Variasi Ketebalan Profil, Tugas Akhir, Universitas Syiah Kuala, Banda Aceh.

[5] Setiawan, A., 2013, Perencanan Struktur Baja dengan Metode LRFD (Berdasarkan SNI 03-1729-2002), Penerbit Erlangga, Jakarta.

[6] Wahyuni, E., 2011, Analisis Struktur Metode Matriks, Institut Teknologi Sepuluh Nopember, Surabaya.

[7] Anonim, 2002, SNI 03-1729-2002 : Tata Cara Perencanaan Struktur Baja Untuk Bangunan Gedung, Departemen Pekerjaan Umum, Jakarta.

[8] Anonim, 2004, SNI 15-2049-2004 : Semen Portland, Departemen Pekerjaan Umum, Jakarta.

[9] Anonim, 2017, SNI 8389-2017 : Cara Uji Tarik Logam, Badan Standarisasi Nasional, Jakarta. 